\title{
Online Marketing Strategy for Sidikalang Arabica Coffee Farmers by Using the Online Marketplace in Desa Parbuluan VI Dairi
}

\author{
Adrian Hilman $^{1,2}$, Elisa Julianti ${ }^{1}$, Rossy Nurhasanah ${ }^{3}$, Niskarto Zendrato ${ }^{3 *}$ \\ ${ }^{1}$ Department of Food Science and Technology, Faculty of Agriculture, Universitas Sumatera Utara, \\ Medan, Indonesia \\ ${ }^{2}$ Integrated Research Laboratory, Universitas Sumatera Utara, Medan, Indonesia \\ ${ }^{3}$ Department of Information Technology, Faculty of Computer Science and Information Technology, \\ Universitas Sumatera Utara, Medan, Indonesia
}

\begin{abstract}
Desa Parbuluan VI is one of the villages in Dairi Regency, North Sumatra province, Indonesia. It was located at 1400 meters above sea level. Thus $60 \%$ of the people in Desa Parbuluan VI work as farmers, especially arabica coffee. The social engagement activities that have been carried out have focused on increasing the online market's understanding as a promotional tool for small business entrepreneurs and farmers in Desa Parbuluan VI. This activity aims to increase public awareness using the online market and expand consumer reach to increase farmer products sales. Some of the methods used are by providing independent socialization and training in online market registration and management. The team immediately created a new account for farmers in online markets such as Tokopedia. Other activities include providing modules and sales support facilities such as product branding on the product packaging. This social engagement activity shows that online marketing strategies can increase sales transactions and generate high economic turnover in improving the living standards of farmers in Desa Parbuluan VI.
\end{abstract}

Keywords: Arabica coffee, Online market, Product branding, Sales transaction Abstrak. Desa Parbuluan VI adalah salah satu desa di Kabupaten Dairi, Provinsi Sumatera Utara, Indonesia. Desa itu terletak di 1400 meter di atas permukaan laut. Dengan demikian, 60\% masyarakat Desa Parbuluan VI berprofesi sebagai petani, khususnya kopi arabika. Kegiatan pengabdian kepada masyarakat yang telah dilakukan difokuskan pada peningkatan pemahaman pasar online sebagai sarana promosi bagi pengusaha kecil dan petani di Desa Parbuluan VI. Kegiatan ini bertujuan untuk meningkatkan kesadaran masyarakat dalam menggunakan pasar online dan memperluas jangkauan konsumen untuk meningkatkan penjualan produk petani. Beberapa cara yang digunakan adalah dengan memberikan sosialisasi dan *Corresponding author at: Faculty of Computer Science and TI J1. Dr. T. Mansyur No.9 USU Medan

E-mail address: niskarto@usu.ac.id 
pelatihan mandiri dalam pendaftaran dan pengelolaan pasar online. Tim langsung membuat akun baru untuk para petani di pasar online seperti Tokopedia. Kegiatan lainnya antara lain pemberian modul dan fasilitas penunjang penjualan seperti merek produk pada kemasan produk. Hasil kegiatan pengabdian masyarakat ini menunjukkan strategi pemasaran online dapat meningkatkan transaksi penjualan dan menghasilkan perputaran ekonomi yang tinggi dalam meningkatkan taraf hidup petani di Desa Parbuluan VI.

Kata Kunci: Kopi arabika, Pasar online, Merek produk, Transaksi penjualan Received 19 Desember 2021 | Revised 18 April 2021 | Accepted 8 June 2021

\section{Introduction}

Dairi Regency is located in North Sumatra Province with 192,780 hectares and is $136 \mathrm{~km}$ from Medan City. It is geographically situated at an average altitude of 400 until 1700 meters above sea level and has 15 districts. Currently, the population of the Dairi Regency in 2015 was 276,328 people, with a population density of 167 people $/ \mathrm{km}^{2}$ [1]. Ecologically, Dairi Regency is a buffer for the Lake Toba ecosystem and contributes most water input through its dozens of rivers.

With an altitude of $200 \mathrm{~m}$ above Lake Toba, Dairi Regency has varying rainfall between 2000-3500 mm/year with an average rainy day of 181 days/year. These conditions (having many wet months) are suitable for growing commodities such as coffee [2]. There are two types of coffee grown in Sidikalang, namely arabica and robusta coffee. The most widely grown species in Sidikalang is the robusta coffee type [3]. However, some farmers still maintain arabica coffee, which has a balanced sour and sweet taste compared to robusta coffee with its bitter taste.

Desa Parbuluan VI is one of the villages in Parbuluan sub-district, Dairi Regency, North Sumatra Province, Indonesia. Desa Parbuluan VI consists of 5 hamlets with 3461 people and 951 family heads, with the majority of the people working as farmers and entrepreneurs. Desa Parbuluan VI is one of the Arabica coffee-producing villages in the Dairi Regency. This village is $137 \mathrm{~km}$ from Medan City. In this village, the Giat Maju Farmer Group produces Arabica coffee on its land. The Giat Maju Farmer Group was founded on April 10, 2017, with 29 members of superior commodities in horticulture, vegetables, corn, and coffee. 
Table 1. Profiles of micro-business partners

\begin{tabular}{lll}
\hline \multicolumn{1}{c}{ Profile } & Description \\
\hline Business Name & Siboro Sidikalang Coffee; Jams Arabica Coffee \\
- & Address & Desa Parbuluan VI, Kecamatan Parbuluan, Dairi \\
- & Type of product & Green bean, roasted bean dan powder coffee \\
- & Raw material & Arabica Coffee \\
- $\quad$ Type of process & Full wash \\
- $\quad$ Land area & 30 acres \\
- & Marketing & Online (Facebook) \\
- Turnover/month & Rp. 2.500.000- \\
- & Profit/month & Rp. $500.000-$ \\
- Employees & 1 \\
- Educational & Senior High School (SMA) \\
& \\
\hline
\end{tabular}

The Giat Maju Farmer Group can produce $100 \mathrm{~kg}$ of green bean arabica coffee every week with around Rp 400-600 thousand. This group's name is "Siboro Sidikalang Coffee" and "Jams Arabica Coffee" in selling its coffee products. Based on the profiles of microbusiness partners in Table 1, it can be seen that the business opportunities and potential of micro-businesses to develop into the best Arabica coffee producer in Dairi Regency, even in Indonesia, are very large. However, the current method used by farmers in marketing their products is only using Facebook. Thus, the target market is unclear and must incur additional costs for advertising. For this reason, farmers need new methods that are more effective and economical so that products are widely marketed.

From these residents' problems, the social engagement team offers solutions to use the online market to expand the promotion of products and services sold by the Giat Maju Farmer Group to reach a wider area [4]. It is hoped that it can improve the welfare of the community around the village. The activities carried out in Desa Parbuluan VI focus on increasing the understanding and skills of the Giat Maju Farmer Group in utilizing the online market as a means of promotion for tiny business entrepreneurs and farmers in Desa Parbuluan VI. The increase in public understanding can expand the market for sidikalang arabica coffee products to increase sales transactions for products. This social engagement activity is expected to increase sales transactions and result in high economic turnover in raising the farmers living in Desa Parbuluan VI.

\section{Methods}

The coffee products produced are only known to the surrounding community and people who are friends on Facebook. Product appearance is also still simple and is not displayed through a particular display room. The method offered for the solution is to provide 
socialization on introducing the type of packaging suitable for partner coffee products so that they have good quality and an attractive appearance. Currently, coffee product sales are still in online marketing, which is spread through groups on Facebook. So that to expand the market, socialization and training will be provided to farmers in using the marketplace and registering partner businesses and products to reach a broader range of consumers.

\subsection{Identify the problem}

The method of Forum Group Discussion (FGD) was used to identify priority problems of farmers and residents in Desa Parbuluan VI. This activity was carried out during the first survey to Desa Parbuluan VI. The social engagement team asked the farmers and residents of Desa Parbuluan VI about the products produced by the farmers, along with the things that were obstacles in carrying out sales activities through online forms (Google Form). From the discussion, it was found that some farmers who are members of the Giat Maju Farmer Group do not have offline and online selling models. In addition, there are still many farmers who do not understand online marketing.

\subsection{Prepare modules and supporting facilities}

The team of social engagement analyzes the availability of facilities to support training activities for online marketing of products, such as electrical resources (resource devices), communication signals (transmission media), appliances (HP/PC/Laptop), modems, and supporting applications.

\subsection{Socialization and training}

The social engagement team assisted in conducting online marketing of sidikalang arabica coffee products using science and technology to support the business activities of the farmers and residents of Desa Parbuluan VI. This socialization and training are expected to be understood and applied by the Giat Maju Farmer Group to facilitate the competitive sidikalang arabica coffee marketing.

\subsection{Mentoring farmer's online shop}

The social engagement team has to encourage the success of the program completed through mentoring as a form of evaluation. Mentoring is necessary so that farmers can maintain the sustainability of their business in online marketing. 


\section{Results and Discussion}

\subsection{Identify the problem}

The social engagement team held discussions to discuss problem-solving techniques considering the limited cost, time, and effectiveness of the methods used. According to the results of the focus group discussions that have been carried out, it was found that of the total number of members as many as 30 people, only about $10 \%$ were familiar with online marketing, and $80 \%$ were not familiar with online marketing and the remaining $10 \%$ did not provide an opinion (Figure 1).

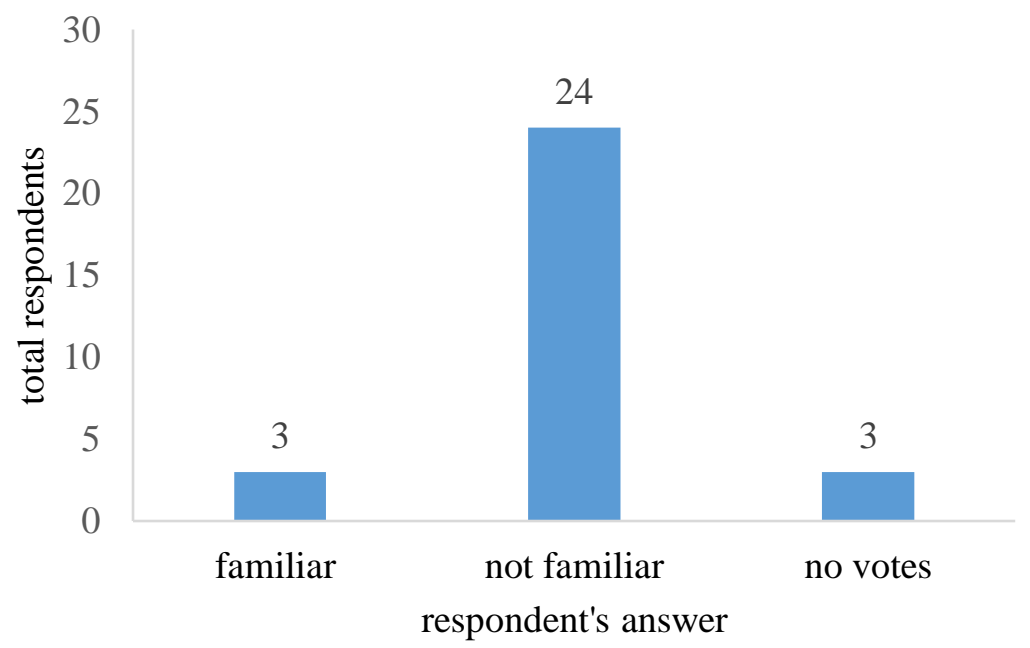

Figure 1. Respondent's answer at FGD

From these results, it was found that farmers needed great socialization and training on online marketing. It is essential to do in the era of the industrial revolution 4.0. Following social engagement activities that have been carried out by [5] stated that online marketing training had motivated so that they do not feel left out by advances in technology information in marketing the product.

The proposed online marketing program offers a solution to the problems faced by the Giat Maju Farmer Group. According to [6], the online marketing concept known as digital marketing gives the best wish for the small and centre industry to develop into a centre of economic empowerment. So, consumers can find and get information about products affordable from the virtual and accessible process of their quest.

\subsection{Prepare modules and supporting facilities}

In this case, it can be ensured that all raw materials are available in the village environment and can be used for problem-solving. The training activities were held on Saturday, July 25, 2020, at the Village Hall of Desa Parbuluan VI. The training activity 
on the use of the online market in marketing sidikalang arabica coffee was opened directly by the Head of Desa Parbuluan VI, which was attended by 30 Giat Maju Farmer Group and residents of Desa Parbuluan VI (Figure 2).

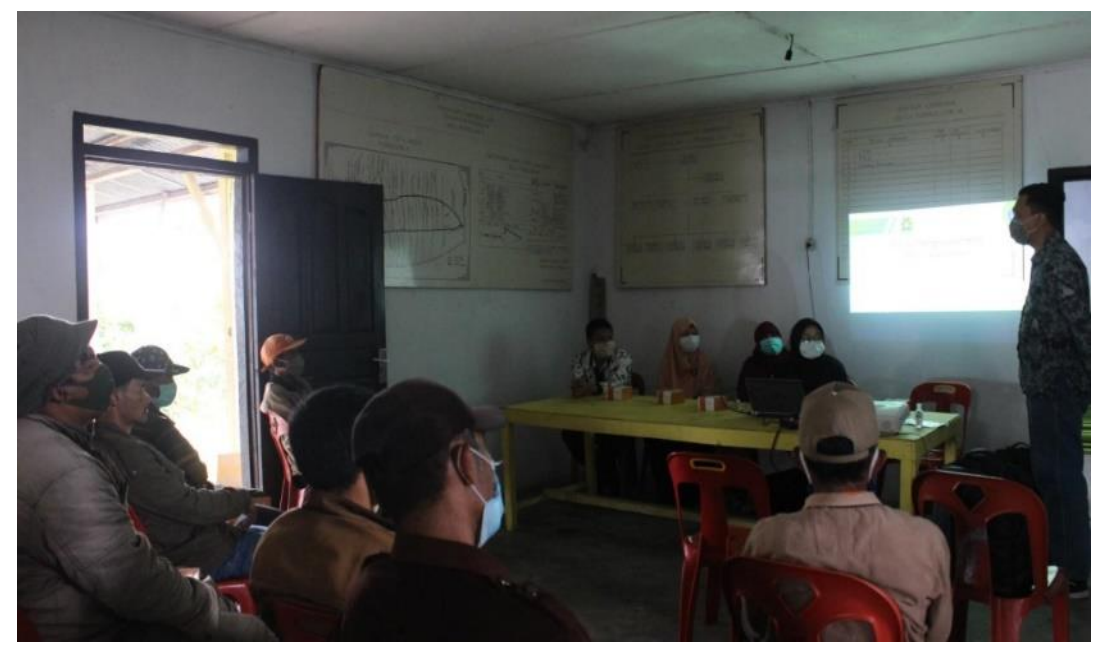

Figure 2. Implementation of social engagement at the hall of Desa Parbuluan VI

\subsection{Socialization and training}

In this training, the benefits of the online market were socialized in marketing sidikalang arabica coffee. The social engagement team explained to the Giat Maju Farmer Group about the benefits of smartphones for social media activities and making money. The following action was to directly train the Giat Maju Farmer Group to create and register their online shop on Tokopedia (Figure 3). Then they also thought about how to upload product photos and set the required parameters.

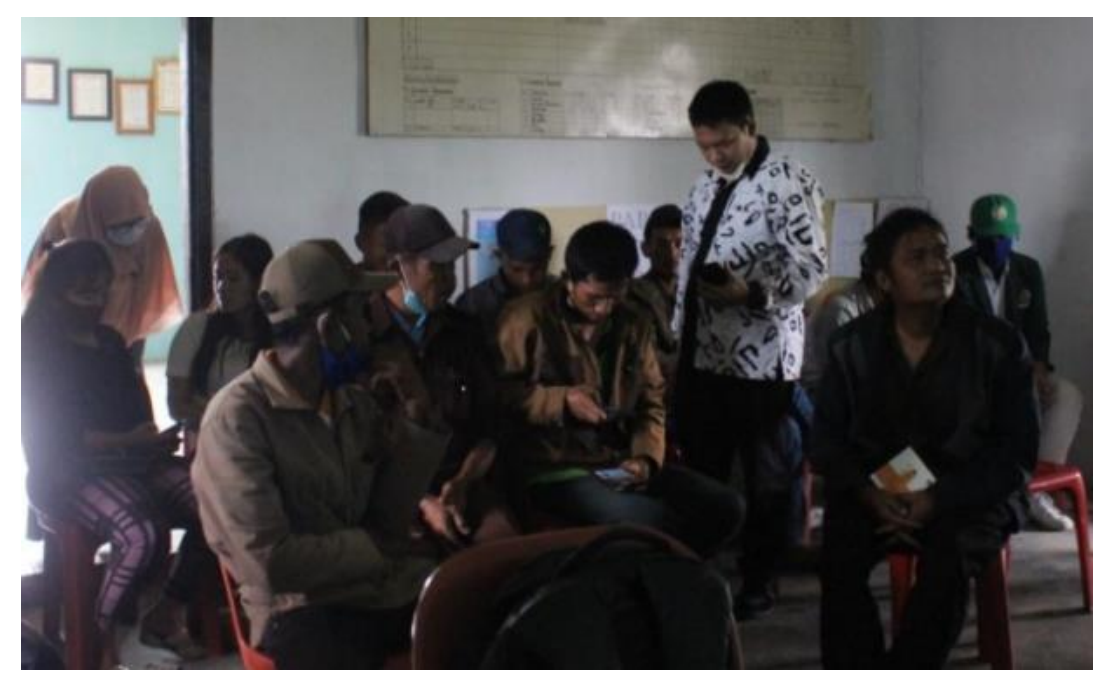

Figure 3. The activity of training online market

Furthermore, the community is guided to an e-economy by new forces global competition, increased information availability, rapid innovations, and increasingly complex products [7]. The social engagement team conveyed the types of business 
opportunities that they can run efficiently and at no cost by using the online market, such as selling pulses, data packages, opening BPJS, PLN, PDAM, and other payment outlets. The social engagement team highly appreciates the residents of Desa Parbuluan VI, who are very cooperative and enthusiastic in participating in this social engagement. It can be seen from the participants' enthusiasm in asking questions and following each step by step directed by the service team. Some of the participants even ran their business directly on their Tokopedia account (Figure 4).

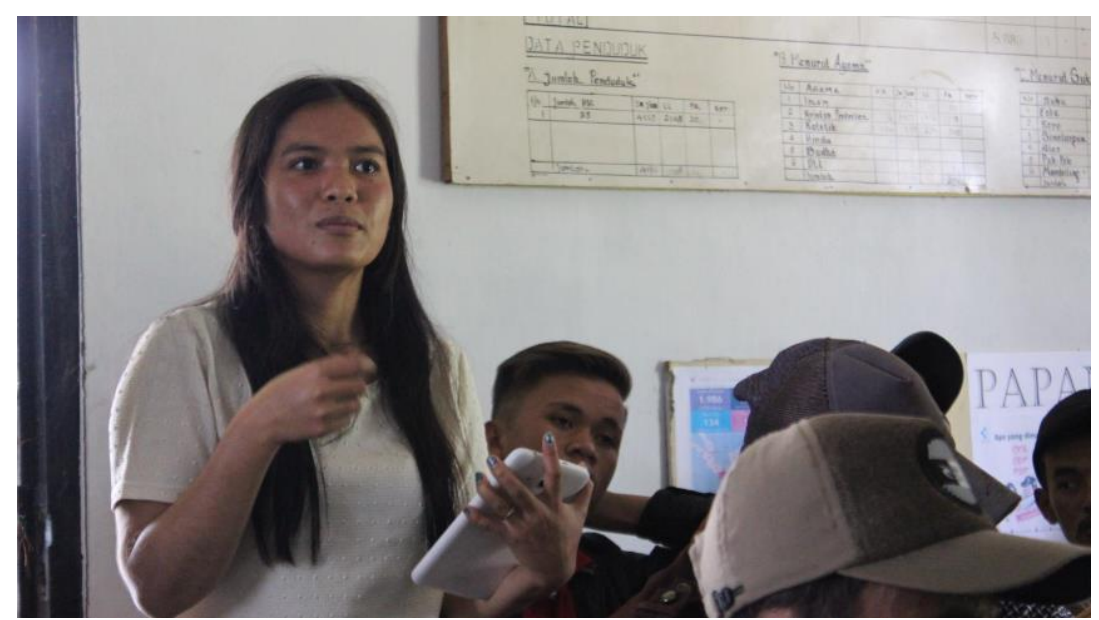

Figure 4. Discussion by residents of Desa Parbuluan VI during training

\subsection{Mentoring farmer's online shop}

The online market training activity ended with an application for residents and farmers of Desa Parbuluan VI to open their first online shop on Tokopedia. Because they have never been familiar with online marketing, social engagement team assistance is needed. Plus, residents and farmers of Desa Parbuluan VI seem to have difficulty managing the accounts that have been created. However, they finally managed to create a ready-tooperate online shop with sidikalang arabica coffee products (Figure 5).

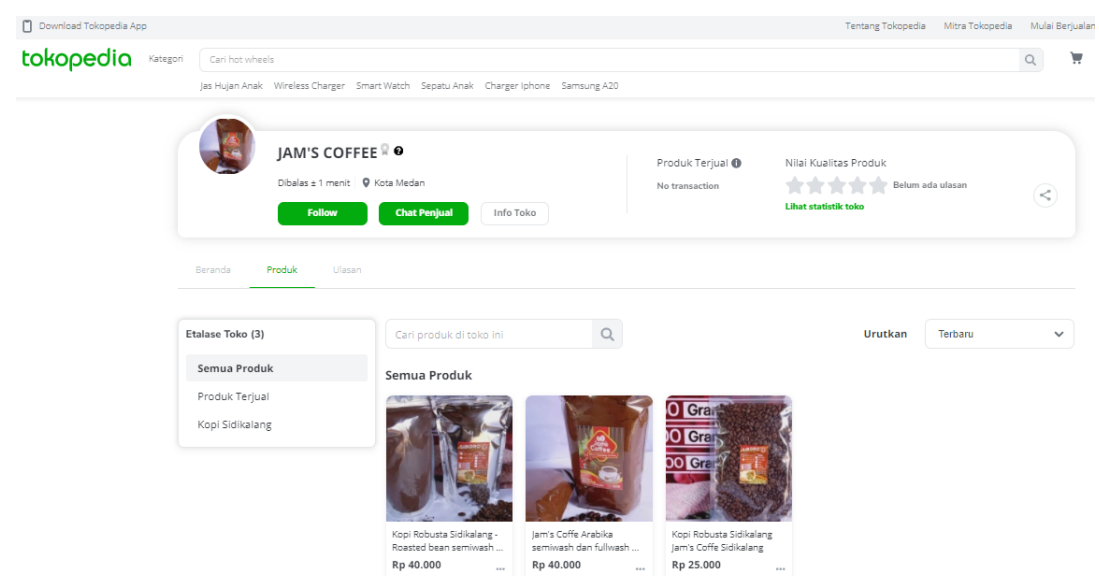

Figure 5. The first online store of Giat Maju Farmer Group 
The Tokopedia account that has been created still needs to be developed for its profile and profile content. Due to the knowledge limitations of the farmers, the social engagement team provided mentoring farmer's online shop after the activity was completed. In addition, evaluation is also carried out through communication via WhatsApp groups, and the social engagement team also provides an assessment questionnaire on the use of the marketplace.

\section{Conclusions}

Training on the use of the online market in promoting sidikalang arabica coffee products in Desa Parbuluan VI can assist residents and farmers in marketing various sidikalang arabica coffee products such as green bean, roasted bean, and coffee powder. The training material can be understood well and is immediately carried out efficiently by the community. It can be seen from the enthusiasm of the residents after receiving the training. Some of the participants immediately used Tokopedia to open an online shop. This training can help residents and farmers to earn more income without capital, one of which is by opening a Payment Outlet that serves various needs of residents and farmers, such as payment of BPJS, payment of electricity and PDAM bills, recharging pulses, or data packages, reservation of train and plane tickets.

\section{Acknowledgements}

This Social Engagement Activity can be carried out thanks to USU's NON-PNBP funding following the contract to implement the Social Engagement Program for the Mono Year of the Young Lecturer for the 2020 fiscal year with a contract number 291/UN5.2.3.2.1/PPM/2020, dated June 9, 2020.

\section{References}

[1] APD Fls, R Govaerts, DM Bridson, P Stoffelen, NB Garden, D Van Bouchout, "An annotated taxonomic conspectus of the genus Coffea (Rubiaceae)". Pp 465-512, 2006. DOI: https://doi.org/10.1111/j.1095-8339.2006.00584.x

[2] BPS DAIRI. Regency of Parbuluan in Number 2020 [Internet]. 2020. Available from: https://dairikab.bps.go.id/publication/2020/09/28/24965e5b11287ed71875b763/ke camatan-parbuluan-dalam-angka-2020.html

[3] BPS DAIRI. Production, Productivity, Number of Farmer Households, Robusta Coffee Region of Dairi 2015 [Internet]. 2015. Available from: https://dairikab.bps.go.id/dynamictable/2017/06/21/78/produksi-produktivitasjumlah-rumah-tangga-petani-tanaman-kopi-robusta-kabupaten-dairi-2015.html 
[4] E Dewi, Berlianti, "Application of science and technology to increase the small production capacity of cake market products". Abdimas Talenta, vol 4, Pp 530-536, 2019. DOI: https://doi.org/10.32734/abdimastalenta.v4i2.4175

[5] Badaruddin, E Revida, L Sudarwati, "Empowerment of "meronce" handcrafts through training of online marketing strategy in order to increase the income of the family in the village of Merawan Dolok, Dolok Merawan, district, online market". Abdimas Talenta, vol 4, Pp 217-226, 2019.

DOI: https://doi.org/10.32734/abdimastalenta.v4i2.4051

[6] B Sembiring, F Sofiah, L Sudradjat, "The Role of Technology Marketing in Business Development UMKM Agents for Repurchase Intention and Its Impact on The Community Satisfaction in North Sumatera". Conference: Prosiding Seminar Nasional Tahun 2018 Publikasi Hasil Penelitian dan Pengabdian kepada Masyarakat Universitas Veteran Bangun Nusantara Sukoharjo, Pp 88-92, 2018.

[7] M Grieger, "Electronic marketplaces: A literature review and a call for supply chain management research". European Journal of Operational Research, vol 144, Pp 280-294, 2003. DOI: https://doi.org/10.1016/S0377-2217(02)00394-6 